\title{
Factors Associated with Work Fatigue Symptoms on Bus Service Officers of PT TransJakarta Corridor VI Ragunan
}

\author{
Mutiara Sakinah Lukman ${ }^{1}$, Mustakim $^{2^{*}}$ \\ ${ }^{1}$ Public Health Program Study, Faculty of Medicine and Health, Muhammadiyah University \\ Jakarta, Indonesia \\ ${ }^{2}$ Public Health Program Study, Faculty of Public Health, Muhammadiyah University Jakarta, \\ Indonesia \\ *corresponding author, e-mail: mustakim.sp76@gmail.com
}

Received: 12/03/2019; Published: 29/09/2020

\begin{abstract}
Background: Work fatigue is a source of problems for workers' health and safety. According to the Ministry of Manpower, data on occupational accidents in 2017 indicate that the number of occupational injuries was 80,392 cases. This study aims to find out factors related to fatigue symptoms on Bus Service Officers of PT TransJakarta, including age, sex, nutritional status, marital status, medical history, workload, work stress, work shift, and ergonomic status. Method: This study uses an analytical descriptive research design with a cross-sectional design, involving 158 Bus Service Officers at Corridor VI Ragunan PT TransJakarta in July 2018. The data collection was conducted by using questionnaires and with univariate and bivariate data analysis. Results: The results show that there was a significant relationship between work fatigue and work stress $(p=0.000)$, workload $(p=0.000)$, ergonomic status $(p=$ 0,000 ). Besides that, there was no relationship between work fatigue and age, years of service, marital status, medical history, and nutritional status. Conclusion: While those who had no significant relationship were sex, nutritional status, marital status, medical history, and years of service, it is suggested that the company should reevaluate the workload, work stress, work shift with perceived fatigue, providing further training on good body position.
\end{abstract}

Keywords: work fatigue; bus service officers; PT TransJakarta

Copyright $(2013$ Universitas Ahmad Dahlan. All rights reserved.

1. Introduction

Symptoms of work fatigue are a source of problems for workers' health and safety. Fatigue can reduce performance and increase the level of work errors that can lead to accidents. Obviously, the problem of work fatigue symptoms is a problem that must be considered because the workforce is a company asset that can affect the productivity of the company (1). Fatigue is one of the risks of a decrease in the health status of the workforce. Symptoms of work fatigue are characterized by the weakening ability of the workforce in carrying out work or activities so that it will increase work errors and occupational accidents as the fatal consequence (2).

The risks of work fatigue symptoms are decreased work motivation, low performance, low work quality, a lot of mistakes, low productivity, work stress, occupational diseases, injuries, and occupational accidents (3). According to some researchers, fatigue can significantly affect workforce health and reduce productivity. Data from the International Labour Organization show that two million workers died from occupational accidents caused by fatigue every year. The study presented $32.8 \%$ or around 18,828 samples out of 58,115 samples who suffered from fatigue (4). 
Both domestic and international research have shown that the number of work fatigue symptoms is still quite high. Research conducted in New Zealand concluded that the symptoms of work fatigue occurred in transportation officers were one of the factors that contributed to occupational accidents, namely about $11 \%$ out of 134 cases (5). In the study of the ergonomic status of work positions and symptoms of work fatigue, $59.4 \%$ of workers experienced a moderate level of work fatigue in sick work posture (ergonomics). Meanwhile, $18.5 \%$ of workers experienced a moderate level of work fatigue in a not-sick work posture (6).

PT TransJakarta is the first bus rapid transit (BRT) transportation in Southeast Asia which has been operated since 2004 in Jakarta. TransJakarta is designed as a mass transportation mode to support the very busy activities of the capital city, with the longest track in the world $(251.2 \mathrm{~km})$ and has 260 bus stops spread over 13 corridors, and operates 24 hours a day. The Bus Service Officers (BSO) are the front officers stationed on the bus, working to maintain the comfort and safety of passengers on the way and provide the necessary information. Therefore, good health is very important to support the BSO work because of the many possible symptoms of work fatigue which occur such as complaints of cramps in the body muscles due to standing for a long time and lack of fluid intake on the way. In order to prevent the occurrence of excessive work fatigue symptoms, the BSO of TransJakarta implement an alternative work system (shift), in accordance with the Republic of Indonesia Labour Law Number 13, Years 2003, Article 77, subsection 2 and 3 on working time regulations, particularly 7 hours in 1 day and 40 hours which can be divided into 5-6 working days.

The work activity is very interesting to be researched on, considering that the work is entirely carried out by using physical strength, where the officers work in a standing position and are responsible for providing information about the bust stops so that it can make the bus service officers thirsty without having enough water to drink. Therefore, this study aims at determining the factors associated with the symptoms of work fatigue on the BSO.

\section{Method}

This analytical descriptive research is quantitative research with a cross-sectional design. The research population was $167 \mathrm{BSO}$ and the sampling of this study used a probability sampling technique, namely proportionate stratified random sampling, by using a hypothesis test formula of 2 proportions and obtained a sample of 158 respondents. The research site was at PT TransJakarta, a Transportation Service, in 2018. The data obtained from the respondents included age, sex, nutritional status, marital status, workload, work stress, work shift, years of service, and ergonomic status. The data were analyzed by using SPSS 20 software with bivariate analysis results.

\section{Results and Discussion}

\subsection{Results}

The results presented in Table 1 show that the factors of work stress $(P R=6,200$; $95 \% \mathrm{Cl}=2,813-13,667 ; p$-value $<0,05)$, workload $(\mathrm{PR}=7,466 ; 95 \% \mathrm{Cl}=3,662-15,223 ; \mathrm{p}$ value $<0,05)$, and ergonomic status ( $P R=8,540 ; 95 \% \mathrm{Cl}=4,137-17,629 ; p$-value $<0,05$ ) significantly correlated with the work fatigue symptoms on PT TransJakarta Bus Service Officers. Meanwhile, the factors uncorrelated with the work fatigue symptoms on PT TransJakarta Bus Service Officers were age $(P R=1,768 ; 95 \% \mathrm{Cl}=0,939-3,330 ; p$-value $\geq$ $0,05)$, years of service $(\mathrm{PR}=0,767 ; 95 \% \mathrm{Cl}=0,408-1,443 ; p$-value $\geq 0,05)$, marital status $(\mathrm{PR}=1,021 ; 95 \% \mathrm{Cl}=0,464-2,246 ; \mathrm{p}$-value $\geq 0,05)$, medical history $(\mathrm{PR}=1,825 ; 95 \% \mathrm{Cl}$ $=0,835-3,992 ; p$-value $\geq 0,05)$, and nutritional status $(P R=1,308 ; 95 \% \mathrm{Cl}=0,680-2,514$; $p$-value $\geq 0,05)$. The details are presented in Table 1 . 
Table 1. Bivariate Analysis of Factors Correlated with Symptoms of Work Fatigue

\begin{tabular}{|c|c|c|c|c|c|c|}
\hline \multirow[b]{3}{*}{ Variable } & \multicolumn{4}{|c|}{ Fatigue Level Classification } & \multirow{3}{*}{ p-value } & \multirow{3}{*}{ PR $(95 \% \mathrm{Cl})$} \\
\hline & \multicolumn{2}{|c|}{ Low } & \multicolumn{2}{|c|}{ High } & & \\
\hline & $\mathbf{n}$ & $\%$ & $\mathbf{n}$ & $\%$ & & \\
\hline \multicolumn{7}{|l|}{ Age } \\
\hline$<24$ y.o. & 42 & 52,5 & 38 & 47,5 & \multirow{2}{*}{0,107} & \multirow{3}{*}{$\begin{array}{c}1,768 \\
(0,939-3,330)\end{array}$} \\
\hline$>24$ y.o. & 30 & 38,5 & 48 & 61,5 & & \\
\hline \multicolumn{6}{|l|}{ Years of Service } & \\
\hline$<6$ months & 38 & 42,7 & 51 & 57,3 & \multirow[t]{2}{*}{0,508} & \multirow{3}{*}{$\begin{array}{c}0,767 \\
(0,408-1,443)\end{array}$} \\
\hline$>6$ months & 34 & 49,3 & 35 & 50,7 & & \\
\hline \multicolumn{6}{|l|}{ Marital Status } & \\
\hline Single & 58 & 45,7 & 69 & 54,3 & \multirow[t]{2}{*}{1,000} & \multirow{2}{*}{$\begin{array}{c}1,021 \\
(0,464-2,246)\end{array}$} \\
\hline Married & 14 & 45,2 & 17 & 54,8 & & \\
\hline \multicolumn{6}{|l|}{ Medical history } & \multirow{3}{*}{$\begin{array}{c}1,825 \\
(0,835-3,992)\end{array}$} \\
\hline Unavailable & 60 & 48,8 & 63 & 51,2 & \multirow[t]{2}{*}{0,185} & \\
\hline Available & 12 & 34,3 & 23 & 65,7 & & \\
\hline \multicolumn{6}{|l|}{ Nutritional Status } & \multirow{3}{*}{$\begin{array}{c}1,308 \\
(0,680-2,514)\end{array}$} \\
\hline Enough & 48 & 48 & 52 & 52 & \multirow[t]{2}{*}{0,522} & \\
\hline Much or Less & 24 & 41,4 & 34 & 58,6 & & \\
\hline \multicolumn{6}{|l|}{ Work Stress } & \multirow{3}{*}{$\begin{array}{c}6,200 \\
(2,813-13,667)\end{array}$} \\
\hline Low & 62 & 59 & 43 & 41 & \multirow{2}{*}{0,000} & \\
\hline High & 10 & 18,9 & 43 & 81,1 & & \\
\hline \multicolumn{6}{|l|}{ Workload } & \multirow{3}{*}{$\begin{array}{c}7,466 \\
(3,662-15,223)\end{array}$} \\
\hline Low & 55 & 67,9 & 26 & 32,1 & \multirow{2}{*}{0,000} & \\
\hline High & 17 & 22,1 & 60 & 77,9 & & \\
\hline \multicolumn{7}{|l|}{ Ergonomic Status } \\
\hline Low & 56 & 69,1 & 25 & 30,9 & \multirow[t]{2}{*}{0,000} & \multirow{2}{*}{$\begin{array}{c}8,540 \\
(4,137-17,629)\end{array}$} \\
\hline High & 16 & 20,8 & 61 & 79,2 & & \\
\hline
\end{tabular}

\subsection{Discussion}

Based on the results, there was a significant relationship between age and work fatigue symptoms on PT TransJakarta Bus Service Officers. From the cut-off point of the median number of Bus Service Officers, respondents under 24 years old experience fatigue more than respondents above 24 years who experience high fatigue. This is not in line with Grandjean's theory which argues that someone's age is in line with their physical capacity to a certain extent and reaches its turning point at the age of 25 . The results of this study are not in line with the previous studies which showed a significant relationship between age and work fatigue. Although there is an age range difference, the behavior or activities done are the same, which tends to be static and has been standardized for a long period. The BSO above 24 years are going through the turning point of their physical capacity, thus they tend to experience faster work fatigue (7). In addition, it is also not in line with other studies stating that the elders tend to experience severe work fatigue caused by the dropping capacity of the organs to be able to perform at their best (8).

The analysis of years of service on the BSO of PT. TransJakarta shows that there was no relationship between the years of service and work fatigue symptoms. Years of service could affect the decreased workability, and higher work errors and accidents. The results of this study agree with the previous study stating that there was no significant relationship between years of service with any work fatigue symptoms $(9,10)$. However, it is different from the research on the officers in Kalimantan Steel that showed a significant relationship (11). Years of service are not related to work fatigue symptoms. It is in line with the results of the study stating that the officers with under 6-month service had a higher fatigue level than those with a more than 6-month service. This is because years of service are related to someone's work experience. The more experienced the BSO are in their job, the more efficient they will be at work. The BSO can control the amount of energy produced while working and know a good or comfortable job position for themselves so that their productivity is maintained. 
The statistics show that there was no relationship between marital status and work fatigue symptoms on the BSO of PT TransJakarta. Marriage increases responsibilities which makes the work appears to be more valuable and important. It is because those who are married will have tasks like learning to live the marriage life, starting a family, taking care of children, managing household, and starting to work. This is relevant to the previous study showing that there was no significant relationship between marital status and work fatigue (12).

Another result shows that there was no relationship between medical history and work fatigue symptoms on the BSO of PT TransJakarta. It is probably because the officers have applied a healthy lifestyle and maintained their health well so that their medical history does not impede them while working. This is different from the previous study stating that there was a significant relationship between medical history and work fatigue $(13,14)$.

This study also shows that there was no significant relationship between nutritional status and fatigue work symptoms on the BSO of PT TransJakarta. The reason probably lies in the factors of individual characteristics, such as weight, height, and different nutrition which effect on different nutritional status for each respondent. The officers with good nutritional status will also have good productivity as a result of the optimal physical capacity of the body organs. This result is in line with the previous study stating that nutritional status was not significantly related to work fatigue symptoms $(15,16)$. However, it is not in line with another study stating that there was a significant relationship between the two variables (17).

The result of this study shows that there was a significant relationship between work stress and work fatigue symptoms on the BSO of PT TransJakarta. This result is in line with the previous study stating that work stress could affect the level of work fatigue symptoms due to the best of work demands and daily needs, causing individuals to compete to fulfill their needs (18). Nevertheless, this result is contradictory to the research on the firefighters in Samarinda (19). Work stress can lead to work fatigue. The fatigue from within individuals is an accumulation process from many factors experienced in the body.

The study finds that there was a significant relationship between respondents' workload with work fatigue symptoms on the BSO of PT TransJakarta. The result is in a line with the previous study stating that there was a significant relationship between workload and work fatigue symptoms (20-22). The increasing number of works needs to be done by the officers will increase the level of workload, and vice versa. If this continues, it might cause excessive workload for the BSO.

This study also significantly shows that there was a relationship between ergonomic status and work fatigue symptoms on the BSO of PT TransJakarta. This is in line with the previous study stating that there was a relationship between ergonomic status and the work fatigue symptoms (23). Due to the works done every day by the BSO, the respondents often get work fatigue symptoms, such as pains in certain body parts, such as right shoulder, left shoulder, waist, lower waist, buttocks, left elbow, right hand, left hand, right thigh, left thigh, right calf, left calf, left ankle, right ankle, and feet.

\section{Conclusion}

The factors of work stress, workload, and ergonomic status had a significant relationship with work fatigue on bus service officers. PT TransJakarta should be able to provide retention and relaxation so that the BSO do not experience stress easily. Furthermore, it is necessary to adjust the workload and posture education so that bus service officers do not experience work fatigue quickly.

\section{References}

1. Notoatmodjo S. Pendidikan dan Perilaku Kesehatan. Jakarta: Rhineka Cipta; 2010.

2. Suma'mur PK. Higiene Perusahaan dan Kesehatan Kerja. Jakarta: CV. Sagung Seto; 2009.

3. Tarwaka. Ergonomi Untuk Keselamatan Kesehatan kerja dan Produktivitas. Surakarta: Uniba Press; 2004.

4. International Labor Organization (ILO). Keselamatan dan Kesehatan Kerja Sarana untuk Produktivitas. 2013. 
5. Beaulieu. The Issue Of Fatigue And Working Time in The Road Transpor Sector. Int Off. 2005.

6. Deyulmar, Birthda Amini dkk. Analisis Faktor-Faktor yang Berhubungan Dengan Kelelahan Kerja pada Pekerja Pembuat Kerupuk Opak di Desa Ngadirekso, Kabupaten Semarang. Jurnal Kesehatan Masyarakat. 2018;6(4):278-285.

7. Rahmawati, Rizki dan Afandi Sabri. Faktor-Faktor yang Berhubungan dengan Kelelahan Kerja pada Perawat di RSUD Bangkinang Tahun 2019. PREPOTIF Jurnal Kesehatan Masyarakat. 2019;3(2):41-45.

8. Atiqoh, Januar dkk. Faktor-Faktor yang Berhubungan Dengan Kelelahan Kerja pada Pekerja Konveksi Bagian Penjahitan di CV. Aneka Garment Gunungpati Semarang. Jurnal Kesehatan Masyarakat. 2014;2(2):119-126.

9. Mallapinang, Fatmawaty dkk. Faktor yang Berhubungan dengan Kelelahan Kerja pada Perawat IGD di RSUD Haji Makassar tahun 2014. Al-Sihah:Public Health Science Journal. 2016;8(1):39-48.

10. Ningsih, Sari Narulita Purwati dan Naffrety Nilamsari. Faktor yang Berhubungan Dengan Kelelahan pada Pekerja Dipo Lokomotif PT. Kereta Api Indonesia (PERSERO). Journal of Industrial Hygiene and Occupational Health. 2018;3(1):69-82.

11. Paulina dan Salbiah. Faktor - Faktor yang Berhubungan Dengan Kelelahan pada Pekerja di PT Kalimantan Steel. Jurnal Vokasi Kesehatan. 2016;2(2):165- 172.

12. Astuti, Ekawati dan Ida Wahyuni. Hubungan antara Faktor Individu, Beban Kerja dan Shift Kerja Dengan Kelelahan Kerja pada Perawat di RSJD Dr. Amino Gondohutomo Semarang. Jurnal Kesehatan Masyarakat. 2017;5(5):163-172.

13. Usman, Syarif dan Indah Yuliani. Faktor-Faktor yang Berhubungan Dengan Kelelahan Kerja pada Karyawan Produksi PT Gerbang Sarana Baja Jakarta Utara. Journal Educational of Nursing (JEN). 2019;2(1):141-146.

14. Apriliani, Ony Linda dan Nurul Huriah Astuti. Faktor-Faktor yang Berhubungan Dengan Kelelahan Kerja pada Petugas Pemadam Kebakaran di Suku Dinas Pemadam Kebakaran dan Penyelamatan Jakarta Selatan. ARKESMAS. 2019;4(1):162-167.

15. Putri, Retno. Faktor-Faktor yang Berhubungan Dengan Kelelahan Kerja pada TKBM di Pelabuhan Pekanbaru Tahun 2015. Collaborative Medical Journal. 2018;1(1):49-59.

16. Wahyuni, Dwi dan Indriyani. Faktor-Faktor yang Berhubungan Dengan Kelelahan Kerja pada Pekerja Bagian Produksi di PT. Antam Tbk. UBPP Logam Mulia. Jurnal IImiah Kesehatan. 2019;11(1):73-79.

17. Permatasari Anjar, farid rezal, Sabril Munandar. Faktor yang Berhubungan Dengan Kelelahan Kerja pada Karyawan di Matahari Department Store Cabang Lippo Plaza Kendari Tahun 2016. Jurnal IImiah Mahasiswa Kesehatan Masyarakat. 2017;2(5):1-11. 18.

18. Jacobs Brian Wisnu P., Paul A.T.K., Franckie R.R.M., Rattu. Hubungan antara Stres Kerja Dengan Kelelahan Kerja pada Bagian Sumber Daya Manusia di PT. Bank Sulut Cabang Manado. Jurnal Administrasi Publik UNSRAT. 2015;1-4.

19. Zelviana dan Kresna Febriyanto. Hubungan Stres Kerja Dengan Kelelahan Kerja pada Petugas Pemadam Kebakaran di Kota Samarinda. Borneo Student Research. 2019;1(1):105-109.

20. Juliana, Mariani dkk. Analisis Faktor Risiko Kelelahan Kerja pada Karyawan Bagian Produksi PT. Arwana Anugrah Keramik, Tbk. Jurnal IImu Kesehatan Masyarakat. 2018;9(1):53-63.

21. Amalia, Izza dan Noeroel Widjajati. Analisa Kelelahan Kerja Secara Obyektif Berdasarkan Reaction Timer pada Tenaga Kerja Unit Pengerolan Besi PT.X. Journal of Health Science and Prevention. 2019;3(1):17-24.

22. Agustinawati, Kadek Rina dkk. Hubungan Antara Beban Kerja Dengan Kelelahan Kerja pada Pengrajin Industri Bokor di Desa Menyali. Jurnal Medika Udayana. 2019;9(9).

23. Arini, Shintia Yunita dan Endang Dwiyanti. Analisis Faktor yang Berhubungan Dengan Terjadinya Kelelahan Kerja pada Pengumpul Tol di Perusahaan Pengembang Jalan Tol Surabaya. The Indonesian Journal of Occupational Safety and Health. 2015;4(2):113-122. 